\title{
Critical Literacy in the ESL Classroom: Bridging the Gap between Old and New Media
}

\author{
Dr. Jena Habegger-Conti \\ The University of Stavanger
}

\begin{abstract}
Research recently conducted at the University of Stavanger found that teachers of English at upper secondary schools experience difficulty in getting their students to read longer fictional texts, and have witnessed negative attitudes towards reading. At the same time, the past four years have shown a $22 \%$ decline in enrolment across Norway in the Literature and Culture subject in the third year of upper secondary. How can the objectives set out in the basic skills section of the English subject specialization program- - "understanding, exploring and pondering demanding texts" - be met if students are losing the cognitive mode of deep attention that helps them read novels and other longer texts? As digital reading has proven to be sloppy, and exhaustive reading is rare online, to what extent can students be expected to gain "insight across cultures and special fields"? Can the overall aims for teaching literature in the ESL classroom, especially those aims regarding the ability to ponder and gain insight, still be achieved through new media and popular culture? This study raises questions concerning the future of reading and offers a critical literacy approach through which teachers and learners can investigate different types of media. Implementing a critical literacy approach in the ESL classroom offers rich possibilities for teaching both language and culture at all levels through both traditional and new media.
\end{abstract}




\section{Critical Literacy in the ESL Classroom: Bridging the Gap between Old and New Media}

Everywhere I went, I heard teachers reporting similar stories, 'I can't get my students to read long novels anymore, so I've taken to assigning short stories'; 'My students won't read long books, so now I assign chapters and excerpts.'

— N. Katherine Hayles, "How We Read: Close, Hyper Machine" (72)

\section{English literature in the twenty-first century}

The situation described in the above quotation was recorded from English teachers in the United States; however, similar attitudes towards reading, and especially towards reading longer texts, are also common amongst Norwegian students of English. Research recently conducted at the University of Stavanger found that teachers of English at upper secondary schools experience difficulty in getting their students to read longer fictional texts, and believe that many students attach negative attitudes to reading as something "that is forced on them" at school, rather than something pleasurable (Herigstad 90). One teacher stated simply: “They don't want to read books" (54).

While these statements reflect teachers' perceptions, and not necessarily the reality of students' beliefs, statistics do show that fewer students are choosing the English Literature and Culture subject in the third year of upper secondary. In four years $(2009 / 10-2012 / 13)$ the number of students nationwide who enrolled in the course dropped 22\% from 1900 to 1600, and some upper secondary schools have stopped offering the course all together (Skogstrøm). Teacher Maaike Grit acknowledged the same trend at her own school, Foss Upper Secondary in Oslo, in a feature article for Norway's national newspaper, Aftenposten: out of 700 students who attend the school, the number who chose English Literature dropped 
from 28 in 2011/12 to only six in 2012/13. Meanwhile, the English subject still remains popular, with 4458 enrolled nationwide in Social Studies English and 10,219 who chose International English in 2012/13 ("Engelsk"). This trend may be related to the perception that English Literature is “old-fashioned”, while Social Studies and International English are thought to deal more with current events and thus perceived as more relevant to the lives of young students (Herigstad 51, 61).

That teenagers are passing over books for more "modern" forms of entertainment is a phenomenon occurring throughout Norway. An annually conducted survey of between 2600 and 2800 Norwegians aged 9-79 shows that in 2013 only $52 \%$ of those aged 16-24 had read a novel, a decrease of $11 \%$ from 2012, and 26\% from 2011 ("Boklesing”). The more astounding figure is that in the previous decade (2000-2010) the number of those from the same age group who claimed to read novels averaged 70\% (“Boklesing”).

While the number of youths in Norway reading novels is in decline, the time spent reading, watching, and playing online has increased dramatically:

\begin{tabular}{|l|r|r|r|r|}
\hline Age & 2010 & 2011 & 2012 & 2013 \\
\hline $\mathbf{9 - 1 2}$ & 35 & 46 & 41 & 57 \\
\hline $\mathbf{1 3 - 1 5}$ & 99 & 106 & 126 & 157 \\
\hline $\mathbf{1 6 - 1 9}$ & 169 & 147 & 153 & 222 \\
\hline
\end{tabular}

Figure 1. Time spent on the internet, by age group, in minutes per day. (From MedieNorge)

The increase in the past three years in the amount of time spent on the internet is particularly steep for 16-19 year-olds, who, in 2013 spent over one hour a day more than they did in 2010 (see Figure 1). This is also two hours and forty minutes more time spent daily than a decade ago, in 2003 ("Internet”). 
It would thus appear that new media is at least indirectly threatening the validity of the subject of English Literature, and possibly linked to the perception that reading a book is "old-fashioned." A looming question, then, is whether students of English will be deprived of the positive benefits associated with reading literature if novels are no longer read and taught in the ESL classroom.

Maaike Grit's article raises concerns about the long-term ramifications of shutting down English literature programs, a loss that implies more than losing a tool for improving one's vocabulary. "Literature", she points out, "allows you to travel in time and space, experience other human minds from within. Nothing else gives this opportunity to insight and maturity. Literature develops us" (1; translation mine). A long list of researchers in literature and education agree that literature is a path to personal development, insight and knowledge (see, for example, Fenner 95-100; Collie and Slater 5-6; Carter and Long 3). In "Reading Novels and Short Stories", Anniken Telnes Iversen remarks on the role of fiction as "an entryway into people and cultures distant from ourselves (which) may therefore encourage cross cultural understanding and help build empathy" (212). She adds, "On a personal level, fiction is a chance to meet others" (212-213). The English subject curriculum in Norway supports these views and claims that "literary texts in English can instill a lifelong joy of reading and a deeper understanding of others and of oneself" ("Purpose" section).

The question, then, is whether only literature can achieve these aims. Although Iversen declares, "The novel is the genre that best deals with what it means to be an individual today", there is no evidence to suggest that the novel will be the genre that best connects with the lives of future readers. In fact, the argument could be made that the traditional novel is the least likely genre to best deal with what it means to be an individual today, at least for those now referred to as "digital natives". Researchers in new literacies like Margaret Mackey point 
out that children are not learning to read in a world of books but in a world of games, films, TV programs and comics.

A possible generational shift in old and new media is already visible at the bachelorlevel specialization in English course ("engelsk fordypning") at the University of Stavanger where this spring only $54 \%$ of those writing a bachelor thesis in English Literature chose to write on traditional novels or short stories. $34 \%$ chose to write on film, and $12 \%$ chose to study the fictional worlds of video games like Mass Effect and Dragon Age through techniques borrowed from literary analysis (narrative, characterization, setting, etc.).

Seeking to demonstrate that all print—not just literary works — is irrelevant to digital natives, Jean-Louis Constanza created a popular two-minute YouTube video from 2011 titled, “A Magazine Is an iPad That Does Not Work", in which his one-year-old daughter is shown interacting with both an iPad and a print magazine. The words "This One Works" appear as his daughter taps her fingers on the screen and giggles and coos while the images move back and forth at the touch of her tiny fingers. The screen goes black and the words "This One Does Not Work" appear. In the next scene the child is shown making the same flicking motions again and again on a completely unresponsive page from a magazine. She is given another print magazine, and again, points and swipes, but to no avail. "Is it Broken or What?" the video asks its watchers, and then flashes the word "Useless." At the end of the video Constanza claims: "Magazines are now useless and impossible to understand for digital natives ... For my 1-year-old daughter, a magazine is an iPad that does not work. It will remain so for her whole life. Steve Jobs has coded a part of her OS". Constanza's description of the video states that it "shows (a) real life clip of a 1-year-old, growing among touch screens and print. And how the latter becomes irrelevant".

By the time his daughter turned three-and-a half, however, Constanza admitted that she had in fact learned what to do with a magazine. The problem was not that the magazine 
was useless to her, but that it appeared so because she had not yet developed the skills necessary to make use of, or "read" the magazine. "Part 2" of the video shows his daughter appropriately using a board book and then coloring on paper behind the superimposed words "no pinch(ing) on books" and "no tap(ping) on paper". Constanza concluded that all media is threatened with irrelevance and it is the responsibility of parents (and presumably also educators) to teach literacy skills and to ensure the continued relevance of reading.

While novels may now seem irrelevant to at least some teenagers in Norway, it is worth remembering that novels were also deemed irrelevant by educators in the early twentieth-century as items of popular culture not suitable for academic study. As Terry Eagleton explains: "In the early 1920s it was desperately unclear why English (literature) was worth studying at all; by the early 1930s it had become a question of why it was worth wasting your time on anything else" (27).

This shift in perception, in which the English subject was seen as fundamental to the contemplation of the human experience, was aided by the efforts of Richard Hoggart, a tutor in adult education in the late 1940s in England. Hoggart attempted to use literary analysis (which at that time was mainly a study of rhetoric) in his class on Shakespeare to scrutinize texts from popular culture, namely newspaper articles, descriptions of gardens in magazines, and advertisements (Hillard 1). Hoggart's methods were guided by the new literary journal, Scrutiny, launched by F. R. Leavis at Cambridge University. Leavis would later be recognized as one of the founders of the practice of New Criticism, the formalist mode of literary theory that reached its height in the 1950 s and was the dominant method of teaching literature in North America and Britain. New Criticism promoted the practice of close reading, a method that could be applied to a variety of materials, whether canonical literature or popular fiction. Its methods revolutionized the teaching of English and, in particular, the teaching of reading. The use of New Criticism for popular fiction like the novel did not make studying 
Shakespeare and the Classics irrelevant; in fact it could be argued that it made earlier texts more relevant by finding new ways to study them, much as theories in postmodernism, postcolonialism and gender studies revitalized studies in areas like Old and Middle English and Shakespeare studies by providing new channels of inquiry.

Jean-Louis Constanza's video, and the history of teaching popular fiction as English Literature, sheds light on concerns for English studies in the twenty-first century. New Criticism made it possible to study popular fiction like the novel at university through the rigorous method of close reading. Similarly, the problem now may not be that literature has become irrelevant, but rather that new methods of approaching literature are needed.

\section{Reading and popular media}

N. Katherine Hayles states: "Now it is time to rethink what reading is and how it works in the rich mixtures of words and images, sounds and animations, graphics and letters that constitute the environments of twenty-first-century literacies" (78). In the past decade definitions of literacy have broadened, and the plural "literacies" is preferred by most theorists, but if we return to Margaret Mackey's claim, what exactly are the specific skills needed to read in a world of games, films, TV programs and comics? And not just read, but to read critically?

Hayles expresses fear that in consuming new media we are losing the critical skills of close reading, a method of scrutinizing small passages of text to focus on individual words with the goal of uncovering what the words, and by extension the author, "really mean". It is a method of analysis that has enjoyed success with the printed novel and short story, forms which can be read and re-read, with key words and passages underlined or circled. Close reading has its share of critics (see, for example, Franco Moretti's Distant Reading), but of 
most concern in this context is that it is an approach that functions best with what Hayles terms "deep attention".

Hayles puts forth the hypothesis that a shift in cognitive modes is taking place in her article, "Hyper and Deep Attention". When reading a long book like a novel, Hayles argues that we need to be able to concentrate, or give "deep attention", to one thing over a long period; new and online media, however, require us to rapidly switch our focus between several tasks at once, and this form of cognitive mode Hayles terms as "hyper attention". Hyper attention desires a high level of stimulation and has a low tolerance for boredom. The difference, says Hayles, is between reading Pride and Prejudice and playing Grant Theft Auto.

Online reading is quicker, and improves skills in skimming, scanning and skipping but, according to Hayles, online reading is also "sloppy in the extreme" ("Close" 66). In an eye-tracking study in 2006, Jakob Nielsen demonstrated that web users do not read text thoroughly, word-by-word, but move across the webpage in an "F" fashion, reading only the first few lines of a text all the way across (the top of the "F"). After this readers typically move only along the left-hand side (the stem of the "F"), meaning that the right-hand portion of the webpage, as well as most of the lower portion of the text, receives very little eyefixation from readers. Nielsen concludes that "exhaustive reading is rare".

Nielsen's "F" pattern confirms a 2005 study at San Jose State University in the U.S., which found that "people reading on screens ... spend more time browsing, scanning, and hunting for keywords compared with people reading on paper...” (qtd. in Jabr). A 2013 study at the Norwegian Reading Centre of the University of Stavanger showed that students scored higher on reading comprehension when they read on paper (Mangen and Kristiansen).

At lower levels of English instruction, online reading may still be a useful tool for learning vocabulary and improving comprehension, but the conclusions from the studies 
mentioned here raise a red flag for teaching English literature at upper secondary schools: how can the objectives set out in the basic skills section of the English subject specialization program ("understanding, exploring and pondering demanding texts") be met if students are losing the cognitive mode of deep attention that helps them read novels? And to what extent can students be expected to gain "insight across cultures and special fields" if exhaustive reading online is rare? Can the overall aims of deep attention and close reading, especially regarding the ability to ponder and gain insight, still be achieved through new media and popular culture?

\section{Critical literacy as a tool for all media}

Richard Hoggart argued that "to assume that popular culture can be explored with crude tools because it is assumed to be crude, uncomplex, easy to read is a serious mistake" (176). In his edited anthology, Reading Pop Culture, Jeff Ousbourne makes a similar point: "mass culture is only mindless if we approach it mindlessly" (7). One resource gaining popularity that offers a thoughtful approach to mass media is critical literacy.

Critical literacy is a lens through which teachers and learners can investigate different types of media, and it offers rich possibilities for teaching both language and culture in ESL classrooms at all levels. The practice of critical literacy developed out of the social justice pedagogy of Paulo Freire, an educator in Brazil in the late 1960s. Since the turn of the millennium it has grown to become a popular approach to teaching English, a movement led in part by Australian researchers Peter Freebody (a core member of the Computer Supported Learning and Cognition Research Centre at the University of Sydney) and Alan Luke. Together they developed the Four Resources Model of literacy education, which was later further developed in Lewison, Flint and Van Sluys' study, "Taking on Critical Literacy", as four dimensions of critical literacy: disrupting the commonplace, interrogating multiple 
viewpoints, focusing on sociopolitical issues, and taking action and promoting social justice (382). The critical literacy approach was also the subject of a panel report in 2004 titled Literacy For Learning for the Ontario Ministry of Education (Canada). Critical literacy is now part of the curriculum for the humanities and social sciences in Ontario.

Central to Freire's teaching methods was the idea that language is never neutral. His book Literacy: Reading the Word and the World reconstructs the idea of literacy as something beyond learning to read and write. In Freire, reading a word is linked to reading the world. Becoming literate is about what people do with literacy — the values people place on various acts and their associated ideologies. In other words, literacy is more than linguistics; it is a political and social practice ... (Van Sluys et al, 199).

In the introduction to the recent book Doing Critical Literacy, Hilary Janks states: "What is important to remember for reading the world critically is that any re-presentation of the world is a version of the world" (11). Janks hyphenates 're-presentation' "to emphasize that the world presents itself to us, and we present it again in the act of re-presentation'. Janks' approach, which is foundational to critical literacy, requires an understanding of a text as a set of choices taken by a text-producer. Texts are not neutral, but are shaped, whether consciously or unconsciously, by the text-producer's beliefs, values, social position, geographical location, and experiences, amongst other things. Both the position of the producer (writer, creator) and the consumer (reader, audience) must be interrogated to practice critical literacy.

Here is where a critical literacy approach moves beyond the older methods of close reading. Instead of looking for what a text, or an author, "really means", critical literacy investigates what a text "really says". For Janks this means asking questions such as, "Who benefits and who is disadvantaged by the position on offer? Who does it include? Who does it exclude? ... Whose interests are served?" (1) 
The end goal of critical literacy is thus twofold: firstly, to help learners to read the world in relation to the structures that influence how choices are made: power, identity, difference and access to knowledge, skills, tools and resource; and secondly, to effect change. According to Freire, education either becomes a means of keeping the status quo, or of freedom, "the means by which men and women deal critically and creatively with reality and discover how to participate in the transformation of their world (Pedagogy 34). Lewison, Flint and Van Sluys follow Freire and propose reframing literacy "as a form of cultural citizenship and politics" (383).

Cultural citizenship — promoting respect between persons of different cultural background and strengthening democratic involvement — is fundamental to the aims and objectives of the Council of Europe language policy: "To promote mutual understanding and tolerance, respect for identities and cultural diversity through more effective international communication" (R(98)6; qtd. in the CEFR 1.2, pg. 3). The Second Summit of Heads of State also prioritized democratic citizenship as an educational objective: "To promote methods of modern language teaching which will strengthen independence of thought, judgment and action, combined with social skills and responsibility" (qtd. in the CEFR 1.2, pg. 4).

These objectives are also explicitly mentioned in the "Purpose" section of the English subject curriculum in Norway:

Development of communicative language skills and cultural insight can promote greater interaction, understanding and respect between persons with different cultural backgrounds. Thus, language and cultural competence promote the general education perspective and strengthen democratic involvement and co-citizenship.

ESL classrooms have traditionally relied on literature, and more specifically on novels, short stories and films, to increase the cultural competency of students. However, these are not the 
only texts our students consume, nor are they the most popular, and critical literacy offers an approach to the English subject curriculum aims across all media, whether digital or print, traditional or popular culture.

\section{Teaching with a critical literacy approach in the ESL Classroom in Norway}

The Norwegian Department of Education published the "Framework for Basic Skills" in January 2013 as "a tool for subject curricula ... to develop and revise National Subject Curricula". The definition of literacy it provides demonstrates an awareness of twenty-first century literacies by incorporating paper, screens and "everything that can be read in different media”, including images:

Reading means to create meaning from text in the widest sense. Reading gives insight into other people's experience, opinion and knowledge, independent of time and place. The reading of texts on screen and paper is a prerequisite for lifelong learning and for active participation in civic life. To read involves engaging in texts, comprehending, applying what is read and reflecting on this. In the context of this Framework, texts include everything that can be read in different media, including illustrations, graphs, symbols or other modes of expression ...

While both the Framework and the English subject curriculum include the aim of reading to provide insight into other points of views and ways of life, they reveal different views on the definition of "text". While the word "text" is broadly understood in the Framework and the main subject area of the English subject curriculum (the latter lists "literary texts and cultural forms of expression from different media" (italics mine)), in terms of teaching culture, the individual competence aims narrow the definition significantly to 
solely "literary texts", which for many means novels, short stories, dramas, and poems (especially given that film is mentioned on its own as a separate category).

The conservative approach to "text" as predominately linguistic and written is understandable in part because the English subject in Norway is still a language subject, and a high competency level in English is not required to read a chart or image. However, as many specialists in second language acquisition point out, language and culture are two sides of the same coin. It is therefore in this regard that critical literacy is deemed useful for investigating words for their meaning within a cultural and historical context.

A critical literacy approach can also address another problem in the ESL classroom related to twenty-first century literacy skills, namely that new media is often taught as "what you see is what you get” (1). The Norwegian Framework for Basic Skills defines digital skills, but offers little that could be useful for literary or critical analysis:

Digital skills involve being able to use digital tools, media and resources efficiently and responsibly, to solve practice tasks, find and process information, design digital products and communicate content. Digital skills also include developing digital judgment by acquiring knowledge and good strategies for the use of the internet.

In teaching the English subject "good judgment" and "good strategies" has tended to focus on the ability to evaluate information on the internet for its reliability (Mifsud 137). Tricia Hedge's Teaching and Learning in the Language Classroom is evidence of this split. In a chapter on reading only one paragraph is given to reading on the internet and it addresses the increasing problem, noted by teachers, of students accessing information through a medium in which "there are no gatekeepers" (215). Hedge's book also includes a sample activity titled "Is it Fools' Gold or the Real Thing?" which asks students to evaluate information from real and fake websites (217). 
While these strategies can be useful for younger students learning to search for information on the internet, twenty-first century media literacy skills at the upper levels of education should develop a deeper critical awareness. According to Ernest Boyer, former president of the Carnegie Foundation for the Advancement of Teaching, skills in media literacy must include learning "how to spot a stereotype, isolate a social cliché, and distinguish facts from propaganda, analysis from banter and important news from coverage" (Cooper 1). Elizabeth Thomas, founder and president of the Center for Media Literacy in the United States defines media literacy as "the ability to be conscious about what's going on around you and not be passive and therefore, vulnerable" (Cooper 1). To be vulnerable in this context is to uncritically accept the preferred meanings that images connote.

According to Stuart Hall's theory of encoding and decoding, visual signs communicate successfully because they connote the dominant ideology of a culture, targeting a "preferred reading" (483). Thus images function on what is commonsense, or taken for granted in a culture. 'It is here, at the level of 'normal common sense,' that ideological frames of reference are most firmly sedimented and most effective," posits Dick Hebdige in his application of Hall's theory to popular and sub-culture (435). Thus visual images — whether in $\mathrm{TV}$, advertising or on news websites - are made to appear natural, as though there is nothing to resist or contest. This is what makes analyzing them particularly difficult, and why the types of questions raised by a critical literacy approach are useful in uncovering the ideological positioning of the image.

An example of approaching visual media through a critical literacy approach in an ESL classroom can be made through a comparison of online coverage of two news stories, one from the U.K's The Independent, the other from the $B B C$ (see Figures 2 and 3). 


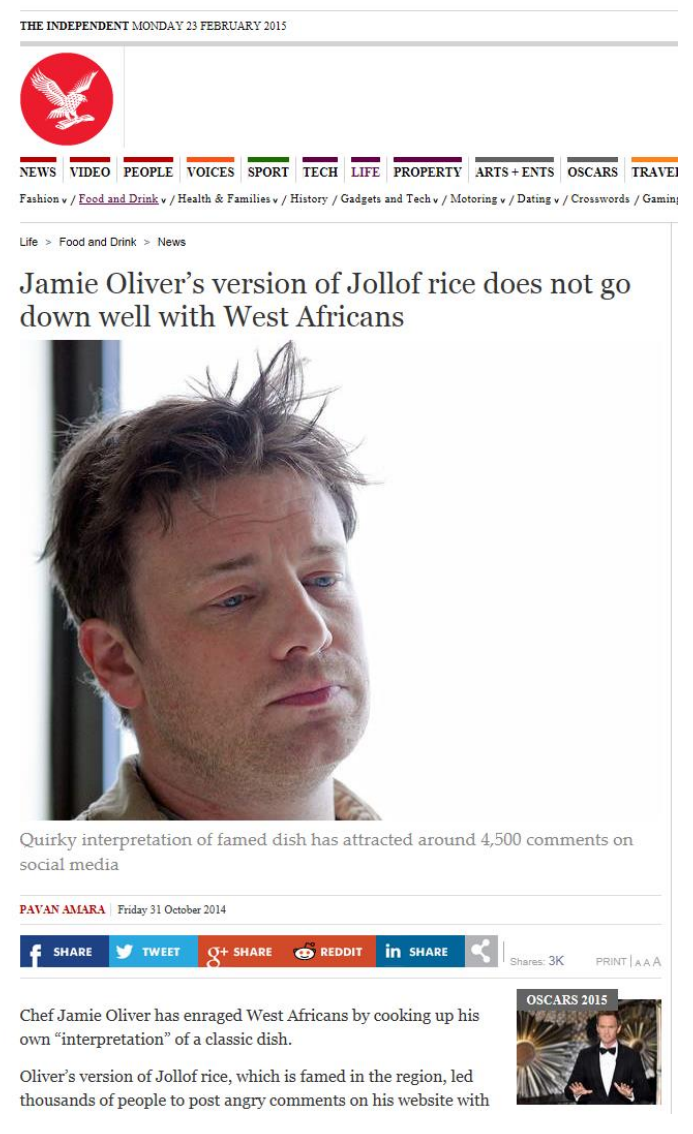

Figure 2. "Jamie Oliver's version of Jollof rice does not go down well with West Africans," The Independent.

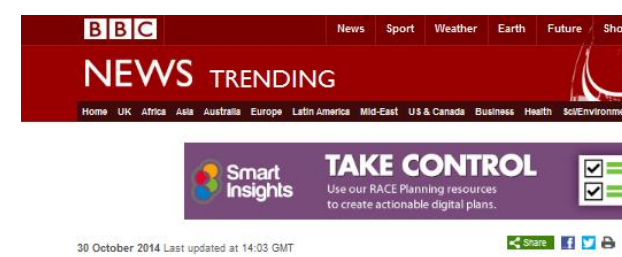

Africans reject Jamie's Jollof rice recipe Bisc $\begin{gathered}\text { By BBC Trending } \\ \text { What's popular and why }\end{gathered}$
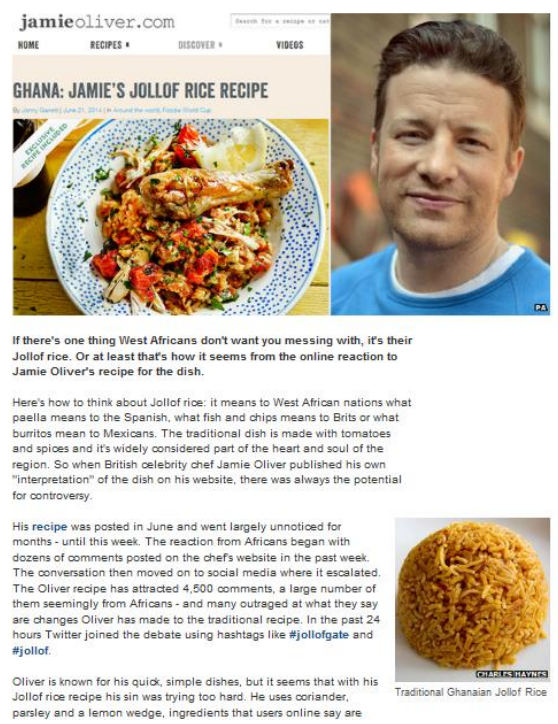

Figure 3. “Africans reject Jamie’s Jollof rice recipe,” $B B C$.

The layout of both websites makes use of Jakob Nielson's F-pattern for reading online, with the photos appearing directly under the headline and the text left-justified in a single column, along the "stem" of the F. However, the photos and accompanying text each tell a different version of the controversy in West Africa over chef Jamie Oliver's recipe for Jollof rice. The Independent's photo tugs at the reader's heartstrings, showing a floppy-haired boy with a disappointed pout. The photo on the right shows a smiling, proud Jamie next to a beautifully prepared dish of colorful food.

A critical literacy approach begins by asking students a series of questions about what they see, and also what they do not see:

1. What / Who?

a. Who or what is in the image? 

b. What do you see?
c. What don't you see?
d. Who is shown?
e. Who is not shown?

2. How?

a. How are people, places or things represented? (Are they as you are used to seeing them?)

b. Shots, angles, lighting, color, eye contact? Etc.

3. Where?

a. How is the image used? (in what context? Social, political?)

b. What is the text's purpose, genre? (advertisement, political cartoon, music video)

(from Janks et al. 85)

Questions about the headline and photo captions are also relevant to understanding the preferred reading of the images. In designing websites according to the " $F$ " pattern of reading, the words or images appearing in the upper left-hand corner become the most important, or prominent. What difference is there when "Jamie" or "Africans" is the first word we read? Is there a difference in meaning between "Africans reject" and "does not go down well with West Africans"?

Exercises such as these help students recognize the ideology present behind the images and their relationship to the text. The $B B C$ 's use of the generalizing word "Africans" (instead of West Africans) and their choice to depict Jamie's meal as colorful and modern (served on a plate), and the traditional Jollof as monochromatic, less nutritious (no vegetable or meat), and apparently served in an unfashionable lump on a table, seems to perpetuate a colonial mentality: the British way is best. 


\section{Conclusion}

Teachers of the English subject have only limited control over the current shift in reading practices away from the novel and towards time spent consuming and interacting with new media. Rather than viewing this as a crisis resulting in the "end of reading," or as signifying impending doom for the English subject, this article has aimed to suggest that teachers of ESL rethink what reading and literacy mean in the twenty-first century to how the subject should be taught, and to positively address these changes. Traditional media like the novel can still be used as a path to personal development, insight and knowledge, but so can new media. While this article has promoted critical literacy as one way to approach new media that requires students to pay closer attention to text and images that might normally be skimmed, more critical approaches that can be used across all media, whether print or digital, must be investigated. In addition, competence aims that include new media must be implemented at the upper secondary level. The problem of reading in the twenty-first century is not how or what our students read, but how we as teachers will ensure that reading continues to be an important component of ESL instruction.

\section{Resources for the ESL classroom}

Some teachers will experience that their students have a higher level of digital and media competence than they do, and Graham Stanley's recent publication Language Learning with Technology: Ideas for integrating technology in the classroom (Cambridge Handbooks for Language Teachers, 2013) can serve as a basic aid for how to find online social networks suitable for classroom use, how to start a class blog or create an online class magazine, etc.

The new book Doing Critical Literacy: Texts and Activities for Students and Teachers by Hilary Janks, et al (Routledge 2014), is an excellent guide for teachers with pages of 
sample activities using grammar, visual literacy, advertising literacy, and digital technology. Accompanying each activity are key questions critical readers should ask of texts.

Catherine Wallace's book Critical Reading in Language Education (Palgrave Macmillan 2003) contains a valuable fifth chapter on teaching critical literacy in the ESL classroom that includes activities and questions for discussion. The book promotes the use of "community texts" (texts "which circulate in everyday life" (104)) that are chosen by the students themselves for study in the classroom. 


\section{Works Cited}

"Boklesing fordelt på type bok - resultat" (Book reading divided by type of book - results). MedieNorge. Online. http://medienorge.uib.no/statistikk/medium/boker/143.

Carter, Ronald and Michael N. Long. Teaching Literature. London: Longman, 1991.

Collie, Joanne and Stephen Slater. Literature in the Language Classroom. Cambridge: Cambridge UP, 1987.

Constanza, Jean-Louis. “A Magazine Is an iPad That Does Not Work”. Online video clip.

YouTube. 6 Oct. 2011. https://www.youtube.com/watch?v=aXV-yaFmQNk

Cooper, Arnie. “Teaching Media Literacy in the ESL Classroom”. Centre for Media Literacy. Online. http://www.medialit.org/reading-room/teaching-media-literacy-esl-classroom Council of Europe, Common European Framework of Reference for Languages: Learning, teaching, assessment. Cambridge: Cambridge UP, 2001.

Eagleton, Terry. Literary Theory: An Introduction. 3rd ed. Minneapolis: U of Minnesota P, 2008.

“Engelsk på vidergående 2012-2013”. Chart. Aftenposten. 15 Oct. 2013. Online. http://www.aftenposten.no/meninger/kronikker/Kunnskapsporter-stenges-i-heleNorge-7325098.html

Fenner, Anne-Brit. "Engelskfagets Utvikling i et Danningsperspektiv”. Fagenes Begrunnelser: Skolens fag og arbeidsmåter I danningsperspektiv. Eds. Kjetil Børhaug, Anne-Brit Fenner, and Laila Aase. Bergen: Fagbokforlaget. 2005. 85-100.

Freire, Paulo. Pedagogy of the Oppressed. Trans. Myra Bergman Ramos London: Bloomsbury Academic, 2000.

Freire, Paulo and Donaldo Macedo. Literacy: Reading the Word and the World. Bergin and Garvey: Westport, CT, 1987. 
Grit, Maaike "Kunnskapsporter stenges i hele Norge" (Gates to Knowledge Closed Throughout Norway). Kronikk. Aftenposten. 15 Oct. 2013. Online. http://www.aftenposten.no/meninger/kronikker/Kunnskapsporter-stenges-i-heleNorge-7325098.html.

Hall, Stuart. “Encoding, Decoding” (1973). The Cultural Studies Reader. Ed. Simon During. London: Routledge, 2007. 477-87.

Hayles, N. Katherine. "How We Read: Close, Hyper Machine”. ADE Bulletin 150 (2010): $67-79$.

---. "Hyper and Deep Attention: The Generational Divide in Cognitive Modes". Profession 2007 (2007): 187-199.

Hebdige, Dick. "Subculture and Style" (1979). The Cultural Studies Reader. Ed. Simon During. London: Routledge, 2007. 429-38.

Hedge, Tricia. Teaching and Learning in the Language Classroom. Oxford: Oxford UP, 2000.

Herigstad, Ane. "The Position and Use of Literature in Norwegian Upper Secondary Schools and the Transition to University". MA Thesis, University of Stavanger, 2014. Print.

Hillard, Christopher. English as a Vocation: The Scrutiny Movement. Oxford: Oxford UP, 2012.

Hoggart, Richard. The Way We Live Now. London: Chatto and Windus, 1995.

“Internett-bruk en gjennomsnittsdag - resultat" (Internet usage, average per day - results). MedieNorge. Online. http://medienorge.uib.no/statistikk/aspekt/tilgang-og-bruk/315. Iversen, Anniken Telnes. "Reading Novels and Short Stories". Literature for the English Classroom: Theory into Practice. Eds. Anna Birketveit and Gweno Williams. Oslo: Fagbokforlaget, 2013. 211-34.

Jabr, Ferris. "The Reading Brain in the Digital Age: The Science of Paper versus Screens", 
Scientific American. 11 April 2013. Online. http://www.scientificamerican.com/ article/reading-paper-screens/.

Janks, Hilary and Kerryn Dixon, Ana Ferreira, Stella Granville and Denise Newfield. Doing Critical Literacy: Texts and Activities for Students and Teachers. London: Routledge, 2014.

Janks, Hilary. Introduction. Doing Critical Literacy Texts and Activities for Students and Teachers. By Janks et al. London: Routledge, 2014. 1-10.

Lewison, Mitzi, and Amy Seely Flint and Katie Van Sluys. "Taking on Critical Literacy: The Journey of Newcomers and Novices”. Language Arts 79.5 (May 2002): 382-92.

Mackey, Margaret. "Pressing Questions: How We Read Now”. Institute for Cultural Studies and Languages, University of Stavanger. 4 Nov. 2013. Lecture.

Mangen, Anne and Marie Kristiansen. “Tekstlesning på skjerm: Noen implikasjoner av et digitalt grensesnitt for lesing og forståelse" (Reading texts on a screen: Some implicadtions of the digital interface for reading and comprehension). Norsk Pedagogisk Tidskrift 1 (2013): 52-62.

Mifsud, Louise. "What Counts as Digital Literacy: Experiences from a Seventh-Grade Classroom in Norway". Mobile Understanding, The Epistemology of Ubiquitous Communication. Ed. Kristoff Nyiri. Vienna: Passagen Verlag, 2006. 133-144.

Moretti, Franco. Distant Reading. London: Verso, 2013.

Nielsen, Jakob. "F-Shaped Pattern for Reading Web Content". NN Group. 17 April 2006. Online. http://www.nngroup.com/articles/f-shaped-pattern-reading-web-content/. Ousborne, Jeff. Reading Pop Culture: A Portable Anthology. New York: Bedford/St. Martin's Press, 2013.

Skogstrøm, Lene. "Elevene velger bort engelsk litteratur på vidergående” (Students Opting Out of English Literature at Upper Secondary). Aftenposten. 2 Oct. 2013. Online. 
http://www.aftenposten.no/nyheter/iriks/Elevene-velger-bort-engelsk-litteratur-pavideregaende-7326385.html.

Stanley, Graham. Language Learning with Technology: Ideas for integrating technology in the classroom. Cambridge Handbooks for Language Teachers. Ed. Scott Thornbury. Cambridge: Cambridge UP, 2013.

UDIR / Utdanningsdirektoratet (The Norwegian Directorate for Education and Training). English—Programme Subject in Programmes for Specialization in General Studies. 1 Aug. 2006. Online. http://www.udir.no/k106/ENG4-01/Hele/?lplang=eng.

---. English Subject Curriculum. 1 Aug. 2013. Online. http://www.udir.no/k106/ENG1-03/.

---. The Framework for Basic Skills. 18 Jan. 2013. Online. http://www.udir.no/Stottemeny/ English/Curriculum-in-English/_english/Framework-for-Basic-Skills/.

Van Sluys, Katie and Mitzi Lewison and Amy Seely Flint. "Researching Critical Literacy: A Critical Study of Analysis of Classroom Discourse". Journal of Literary Research 38.2 (2003): 197-233.

Wallace, Catherine. Critical Reading in Language Education. London: Palgrave Macmillan, 2003. 